\title{
Questions and speech genres in social studies classrooms
}

\author{
Comparisons of communication patterns
}

\author{
Christina Osbeck
}

In this essay, observed communication patterns in two social studies classes in a Swedish middle school are analysed. Social studies is an interdisciplinary subject area consisting of religion, history, geography, and civics. The two classes of 12-year-old pupils, here termed $A$ and $C$, are part of a research project where previous analyses have shown that the classes' average results and development in a knowledge test in religious education (RE) (religionskunskap) conducted at the beginning and end of the academic year 2011-2012, showed statistically significant differences. The research question of this essay concerns the kinds of communication patterns in the two classes that may contribute to an understanding of the identified differences in achievement and development, as defined in the RE test.

It is known from previous studies that the particular class being taught says a great deal about any differences in achievement. A recent Swedish study shows, for example, that about 25 per cent of the variance in the results of a national science test could be explained by looking at the pupil group (Bach et al. 2015). There are certain characteristics in teaching that are known to affect differences in achievement (for example, Nordenbo et al. 2008; Hattie 2009). One way to describe this is used by Hattie in his comparison of expert 
teachers and experienced teachers (2003). The experts distinguish themselves from experienced teachers with their deep and multifaceted understanding of the subject, which can mean problematising current themes and linking themes to previous teaching. Expert teachers are also more alert to classroom climate and relations, which can mean adapting their teaching to specific pupil groups, caring for and having high expectations of the pupils, and creating an atmosphere where they are not afraid to make mistakes. A focus on goals and working processes is also characteristic of expert teachers, which can mean being explicit about goals and expectations, focusing on what the pupils know and gaps in their knowledge, giving relevant feedback, and formulating challenging tasks.

Another way of summarising research on what enhances pupils' learning is, like Hattie (2009), to stress the importance of making learning visible, creating a joint focus for teachers and pupils concerning what to learn, pupils' current knowledge, and necessary steps to take. Questions asked by both teachers and pupils therefore matter since they show not only the direction for learning but also the current knowledge position to work from. Small-scale qualitative studies are a valuable way to examine the potential uses of teacherpupil communication, and what in certain situations hinders and facilitates informative interaction. Such studies in mathematics and science education have shown that teachers' questions tend to be more topical and procedural than conceptual, which means that they are more focused on facts and acts than deeper understanding (Emanuelsson 2001). Moreover, questions have been shown to be an important tool for teachers when helping their pupils translate their questions from everyday language into a scientific idiom in order to develop their understanding (Lundin 2007).

\section{The research project and context of the study}

This essay is based on a Swedish project in which three Year 6 classes-located in different towns-were observed. About 80 lessons were audio recorded and transcribed. An RE test was designed according to the requirements of the Swedish curriculum, in which RE has 
since the 1960 s been described as a neutral and plural subject. It is compulsory and includes four core content areas: 'Religions and other outlooks on life, 'Religion and society', 'Identity and life issues' and 'Ethics' (Skolverket 2011, 178-80).

The first empirical article from the project focuses on teachers' perspectives (as described in interviews) and pupils' perspective (as expressed in the RE pre-tests). These perspectives were examined as conditions for teaching and learning (Osbeck 2014). The study shows that the pupils' perspectives at the beginning of the year were far removed from the intentions of the curriculum. For instance, the pupils' statements concerning religion as a phenomenon were vague-some even confused 'religion' and 'region'-and their interpretations of religious symbols are therefore hard for them to use in further analyses. A problem for the teachers was that they lacked knowledge about pupils' difficulties in RE, which affected their ability to direct teaching. One teacher, Hans, was an exception: he noticed that pupils had difficulties with comparing, finding connections, and thinking of life in an abstract way, and therefore used classroom communication so that the pupils had the opportunity to develop by encountering such perspectives expressed by others. Furthermore, the teachers' intentions-their RE goals in relation to the curriculum-were rather general, and primarily related to fostering fundamental values.

The second article focuses on the relation between the pre- and post-tests (Osbeck 2017). The findings show that a progression in test results between autumn and spring can be identified in all three classes, and that there were differences between the classes both in achievement levels and development. This is interpreted as an indication of the variation in the ways of facilitating RE learning in the classroom. In addition to this, the test also provided information about pupils' communication patterns both in and outside school, and about their general school experience, making it possible to examine whether this related to their RE test scores. Of these factors, 'asking questions' when one is curious or does not understand appears to be important. The largest achievement differences were between classes $\mathrm{A}$ and $\mathrm{C}$, and the test also shows statistically significant 
differences between classes in the pupils' willingness to ask questions during whole-class activities: the pupils in Class A, where both the achievement level and development were lower, were less interested in doing so. The essay's findings led to the current study, which examines what more can be said about the communication patterns in classes $\mathrm{A}$ and $\mathrm{C}$, which may contribute to an understanding of the differences in achievement.

\section{The broader RE research context of the study}

Empirical studies concerning the relationship between teaching and learning are rare when it comes to RE, the didactical subject matter of this study. One quantitative study in which about 2,500 pupils in Year 5 participated shows that it is harder to explain achievements in RE than it is in mathematics and Greek. The study also suggests that individual factors - such as previous knowledge, sex, and socioeconomic status-explain more variance than do classroom factors. Nevertheless, the study emphasizes that ways of structuring teaching and asking questions-not only their frequency, but also their focus, quality, and timing - are of importance (Kyriakides \& Creemers 2008).

There have been some qualitative classrooms studies, although their interests differ from the current study. A few have looked at how communication patterns create specific understandings of religions as a phenomenon (for example, Afdal 2015; Kittelmann Flensner 2015; Lippe 2011; Osbeck \& Lied 2012), and have demonstrated the influence of a plural and secular society. Others have focused on identity politics, subject formation, and the construction of societal hierarchies that take place in RE, where pupils are labelled and anyone who is religious tends to be constructed as 'the other' (Buchardt 2008; Karlsson 2015; Nicolaisen 2013). A couple of these studies can also be said to examine what kind of school subject-what kind of RE subject-is being constructed (for example, Karlsson 2015; Kittelmann Flensner 2015). The study that can be said to be closest to the current one, because it examines teachers' strategies and meaning-making in classroom interaction, is Liljestrand (2002); 
however, as Liljestrand focuses on the discussions in RE and civics in upper-secondary school that centre on controversial societal issues and looks at the potential of these discussions in educating democratic citizens, neither his study nor RE didactic classroom studies as a whole provide the current study with much to draw on.

\section{Task, theory, and tools}

The research question to be examined here is what communication patterns in Class A and Class C may contribute to the differences noted in achievement and development, as defined in an RE test. This task requires a description of what is meant by knowledge, subject-matter knowledge, and learning in the context of this study. Knowledge, then, is understood as intimately linked to language, and learning is understood to be linked to the development of language. Such a perspective is stressed in a socio-cultural approach to learning, where language, according to Vygotsky, is the tool of tools that mediates our being in the world (for example, Säljö 2005, 81). Subject-matter knowledge can be understood as the language of certain spheres of reality (for example, Postman 1998; Skogar 2000) and RE knowledge, given its dual aim of learning about and from religions (Grimmitt 1987), as both a 'language of religions' and a 'language of life' (Osbeck 2009). Well-developed language makes it possible to think, speak, and act in a richer and more nuanced way. However, language is not something that one has or does not have, but rather it is used and developed in practices that privilege various kinds of languages (Wertsch 1991, 14; Tappan 1992).

The varied contexts where we participate and develop linguistically are discursive practices. A school class can, in an overarching sense, be understood as one discursive practice, but can also on closer examination be understood as consisting of many discursive practices, linked to different tasks. Speech genres are specific ways of speaking in these practices that also regulate content, since form and content are interrelated (Bakhtin 1986, 60). The negotiation of a hegemonic speech genre is the negotiation of content and content learning that is made possible (cf. Lundin 2007). Speech genres that 
become hegemonic in a practice are related to the social ideals of these practices-in other words, interpretations of what it means to be a competent actor, since such competences include mastering hegemonic speech genres. Thus learning can to a large extent be understood as appropriating a practice and becoming a competent actor in that practice (Säljö 2005, 140). However, in a discursive practice, there are different positions such as teacher or pupil, and consequently learning takes different directions depending on one's position (Säljö 2005, 87-8; Foucault 1989).

In a previous study of textbooks as part of this project, communicative activities (Englund 2000, 44) were interpreted as links between discursive practices and hegemonic speech genres. I suggested, on the basis of an analysis of RE curricula in Swedish compulsory school from 1962 on, that there are central kinds of communicative activities in RE, and I distinguished between the informing, analysing, interpreting, existential-interpreting, and narrative activities in RE (Osbeck 2013). However, the distinction between communicative activities and speech genres is hard to maintain. Communicative activities can also be understood as Bakhtian speech genres of sorts. Informing activities were defined as those that 'address certain facts as part of established knowledge', analysing activities as those involving 'two or more perspectives that are being related to each other' (Osbeck 2013). Interpretative activities also refer to two or more perspectives, but where 'one of the perspectives is related to the learners' experience'. An existential-interpretative activity is one where 'questions about meanings in relation to one's own life and one's purpose in life are raised' and narrative activities were self-explanatory (155). The division shows similarities with Bloom's taxonomy of educational objectives (see, for example, Krathwohl 2002).

In the following examination of communication patterns, the concepts of speech genres, discursive practices, positions, and competent actors are central. The first step focuses on teacher questions (not all teacher statements) and pupil questions and comments, and analyses frequency, unanswered teacher questions, whether questions were open or closed (cf. Liljestrand 2002), and the form and content of the speech genres. It should be stressed that speech genre here, for 
analytical reasons, is studied first from the perspective of form and only thereafter from the perspective of content, but as already noted speech genre must be understood as an intertwined phenomenon in this respect. The second step interprets these analyses with a focus on how positions are performed and competent actors are highlighted in the two discursive practices ( $\mathrm{A}$ and $\mathrm{C}$ ), and what it may mean to learn and appropriate these discursive practices as wholes.

In order to compare the communication patterns in the two classes, lessons that were as similar as possible in focus have been chosen so that the differences are as visible as possible. Two introductory lessons about the study of religion and two lessons where the classes worked with a news quiz have been analysed. Due to the limitations of space, the quiz analyses are represented primarily as summaries, focusing on whether the patterns identified from the RE lessons are confirmed or called into question by the findings from the news quiz.

\section{The classes and teachers}

Class A, which has 33 pupils, is taught by Christer and Elisabeth, who every year teach new classes of Year 6 pupils in order to make the transition from middle school to lower-secondary school smoother. This particular class was made up of pupils who had been in two separate classes the previous year. The teachers use a flexible system of grouping the pupils, which is why there are two teachers for 33 pupils, rather than having two groups with one teacher each. Generally, they start with the whole group and then continue with individual work. The teachers describe the school district as a mixture of two housing areas: one dominated by homeowners, the other by rental accommodation. 74 per cent of the pupils' parents had a post-upper secondary education (Skolverket 2015).

In Class $\mathrm{C}$, Hans teaches 16 pupils. He has been their class teacher for two years and also taught them RE the year before that. The school is located in a small dormitory town where more than 50 per cent of its inhabitants commute. The area is dominated by detached houses and 65 per cent of the school's parents had post-upper secondary education (ibid.). 


\section{The lessons}

In Class A, the introductory RE lesson was Year 6's first social studies lesson to focus on religion. It lasted about 40 minutes. Class $\mathrm{C}$, meanwhile, had had a revision lesson before the introductory one in which they had recapitulated the RE teaching from previous years, which had focused on how Christianity arrived and developed in Sweden. Now in the introductory lesson to the Year 6 RE, they are to 'focus on what it's like in the rest of the world', as Hans says in his introduction to the 60-minute lesson (see Table 2.1).

There are clear similarities between the two lessons given to classes A and C. Hans and Elisabeth, whose colleague Christer remains passive during this lesson, focus on the spread of different religions in different regions of the world and use the same introductory film. Both lessons can be divided into four sequences. Elisabeth starts by defining religion and reading the national goals for $\mathrm{RE}$ that have been printed out and stuck on a cupboard. In the second sequence, the spread of religions is in focus, and Elisabeth informs her pupils about this orally and with the help of two maps: a world map available in the classroom and another that she has drawn in order to show the spread of religions. The third sequence is when the film is shown (20 minutes - not analysed here) and in the fourth sequence, Elisabeth concludes by stressing similarities between religions, such as the Golden Rule and a belief in life after death. In Class C, Hans starts by going over the previous revision lesson for a pupil who had been absent. In the second sequence, he focuses on the spread of the religions by getting the pupils to read a textbook (including maps) and by using the map of the world. He continues, thirdly, with small-group discussions about the pupils' knowledge of world religions (20 minutes-not analysed) and the film constitutes the final sequence (again, not analysed here).

In the two classes' work with the same news quiz there are two main sequences. Firstly, the pupils are supposed to answer the questions individually; secondly the correct answers are called out. The analysis here focuses on the teachers' and pupils' comments and questions rather than the actual quiz. While the pupils read the questions in 


\begin{tabular}{|c|c|c|}
\hline & $\begin{array}{l}\text { Class A; } 40 \text { min (20 min film - not } \\
\text { analysed) }\end{array}$ & $\begin{array}{l}\text { Class C; } 60 \text { min ( } 20 \text { min } \\
\text { group discussions + } 20 \\
\text { min film - not analysed) }\end{array}$ \\
\hline Questions teacher & 10 & 12 \\
\hline Questions/comments pupils & 2 (1 question +1 comment) & 9 \\
\hline Unanswered questions teacher & 3 & 0 \\
\hline Open questions teacher & 4 & 5 \\
\hline Closed questions teacher & 6 & 7 \\
\hline Open questions pupils & 0 & 5 \\
\hline Closed questions pupils & 1 & 4 \\
\hline \multicolumn{3}{|c|}{ Speech-genre form of the questions/comments } \\
\hline Informing & 8 (7 teacher +1 pupil) & 7 (4 teacher +3 pupil) \\
\hline Analysing & 2 (1 teacher +1 pupil) & 8 (4 teacher +4 pupil) \\
\hline Interpreting & 2 (teacher) & 6 (4 teacher +2 pupil) \\
\hline Existential-interpreting & 0 & 0 \\
\hline Narrative & 0 & 0 \\
\hline \multicolumn{3}{|c|}{ Speech-genre content of the questions/comments } \\
\hline Geography/Religion & 6 (teacher) & 13 (7 teacher +6 pupil) \\
\hline Learning and thinking processes & 1 (teacher) & 4 (3 teacher +1 pupil) \\
\hline Churches & 0 & 1 (pupil) \\
\hline Archaeology/History of religions & 3 ( 2 teacher +1 pupil) & 0 \\
\hline Phenomenology of religions & 1 (teacher) & 0 \\
\hline Source criticism & 1 (pupil) & 0 \\
\hline Concepts & 2 (teacher - included above) & 3 ( 2 teacher +1 pupil) \\
\hline
\end{tabular}

Table 2.1. Communicative patterns during the two lessons "Introduction to the study of religions" in Classes A and C.

the first sequence in Class $C$, Christer reads the questions to the pupils in Class A (see Table. 2.2). The quiz takes slightly longer than 30 minutes in Class $\mathrm{C}$, and just less than 20 minutes in Class $\mathrm{A}$.

\section{Teacher questions and pupil questions/comments}

In the introductory RE lessons, the numbers of teacher questions in the two classes are almost the same, with a slight predominance of closed questions in both. However, the number of pupil-initiated questions and comments is much higher in Class C (9 versus 2). In Class A, Elisabeth also has difficulties getting answers to her questions in almost half of her attempts. On one of these occasions, she manages to get a 


\begin{tabular}{|c|c|c|}
\hline & Class A (20 minutes) & Class C (30 minutes) \\
\hline $\begin{array}{l}\text { Questions/comments } \\
\text { teacher }\end{array}$ & $\begin{array}{l}11 \text { (6 questions + } 5 \text { com- } \\
\text { ments) }\end{array}$ & $\begin{array}{l}24(12 \text { qu }+11 \text { co + 1- } \\
\text { mixed })\end{array}$ \\
\hline $\begin{array}{l}\text { Questions/comments- } \\
\text { pupils }\end{array}$ & 4 (comments) & $\begin{array}{l}19 \text { (9 questions + 10- } \\
\text { comments) }\end{array}$ \\
\hline $\begin{array}{l}\text { Unanswered questions- } \\
\text { teacher }\end{array}$ & 1 & 2 \\
\hline Open questions teacher & 2 & 6 \\
\hline Closed questions teacher & 4 & 6 \\
\hline Open questions pupils & 0 (only comments) & 2 \\
\hline Closed questions pupils & 0 (only comments) & 7 \\
\hline \multicolumn{3}{|c|}{ Speech genre form of the questions/comments } \\
\hline Informing & 15 (11 teacher +4 pupil) & $\begin{array}{l}31 \text { (18 teacher + 13- } \\
\text { pupil) }\end{array}$ \\
\hline Analysing & 0 & 3 (teacher) \\
\hline Interpreting & 0 & 3 (teacher) \\
\hline Existential interpreting & 0 & 0 \\
\hline Narrative & 0 & 6 (pupil) \\
\hline \multicolumn{3}{|c|}{ Speech genre content of the questions/comments } \\
\hline Political science & 4 (teacher) & 8 (3 teacher +5 pupil) \\
\hline Task-solving processes & 5 (teacher) & 12 (7 teacher +5 pupil) \\
\hline $\begin{array}{l}\text { Words, pronunciation,- } \\
\text { abbreviations }\end{array}$ & 2 (teacher) & 6 (5 teacher+ 1 pupil) \\
\hline Jokes & 4 (pupil) & 1 (pupil) \\
\hline Links, contexts & 0 & 5 (4 teacher +1 pupil) \\
\hline Geography/map & 0 & 4 (1 teacher +3 pupil) \\
\hline $\begin{array}{l}\text { Society and culture } \\
\text { generally }\end{array}$ & 0 & 7 (4 teacher +3 pupil) \\
\hline
\end{tabular}

Table 2.2. Communicative patterns during the two lessons "The news quiz" in Classes $\mathrm{A}$ and $\mathrm{C}$.

reply by guiding the process and giving clues, but is not satisfied with the answer and instead gives the answer she had in mind.

In the other situations, her questions remain unanswered and instead are answered by Elisabeth herself, as in the following example where she refers to the seen film: 
E: Religion... Does any one of you remember... caught what religion means... [None of the pupil respond] That it was an intertwinement of people and a higher power...

Hers is a very broad question, both fundamental and multifaceted, while the answer that she seems to expect and later gives is quite specific, but also abstract and hard to understand. In addition, it differs from two other definitions given earlier. The pupils do not respond to the question and the content. While there are no unanswered questions in Class C, it seems from Elisabeth's comments that she is used to unanswered questions. She expresses negative expectations on a couple of occasions in the formulation of her questions: 'Anyone who has an idea?' Unsuccessful communication and failed subject-matter exchanges are not unexpected.

When the analyses of the two news-quiz lessons are added, another difference becomes apparent, since here too the teacher questions/ comments are more common in Class $\mathrm{C}$ than in Class A. In line with previous findings, the frequency of the pupils' questions and comments are more numerous in Class $\mathrm{C}$, while there is no clear difference between the number of closed and open questions in the two classes. In both classes there are unanswered teacher questions, but they seem to surprise Hans and his pupils more than they do Elisabeth and her pupils.

It is worth stressing that all four pupils comments in Class A are sarcastic remarks or jokes about difficulties with the quiz and incorrect answers. When, for example, Christer reads the response options to the question about which fairy tale was written by the Danish author Hans Christian Andersen and one of the alternatives is Mio, My Son, the title is repeated by some of the pupils in an artificial, almost shocked but amused way. Such comments go unchallenged in Class A, while both the teacher and one of the pupils in Class $\mathrm{C}$ react to a similar comment:

6: Åland Islands belongs to a Nordic country, which one? 1 Denmark, 2 Norway, or 3 Finland?

10: That was difficult... [sarcastically] 
$\mathrm{H}: \mathrm{Sh} !$

8: Well, I have no idea...

The teacher rejects the comment by hushing the pupil and is immediately backed up by another pupil, who draws attention to not only the oddness of the first pupil's behaviour but also the possibility of admitting ignorance in the classroom.

\section{Speech genre forms}

The speech genres also differ between the two classes. While Class A is heavily dominated by an informing genre, the distribution between informing, analytical, and interpreting forms is more equal in Class $\mathrm{C}$ and therefore more varied.

An example of an informing speech genre is the question about the religion 'which is the most common where we live... Is there anyone who knows what religion I'm looking for?' (Elisabeth). The expected answer is one word: Christianity. Elisabeth also uses the map as a tool that might facilitate the informing practice and help answer the questions.

E: These religions are spread out in different places in the world. We have made a map where we have drawn... . Here you can see that one religion is very big and very widespread, and it is represented, not in all parts of the world, but in almost all parts of the world... which one is it?

Since the information obtained from analysing the map is the same as the information given in the question itself (that the religion is large and represented in most parts of the world), the map can hardly be taken to be an analysing tool.

In Class $\mathrm{C}$, they also work with maps, but here Hans formulates the questions so that the answers require more information gatheing and analysis. 
[After one of the pupils has read out a text about Judaism from the textbook.]

$\mathrm{H}$ : Judaism emerged in Israel, fine, but where is that? Where is Israel? Can someone come forward and point out where it is located?

The map is here used as a tool to clarify the information given in the textbook; the practice of doing an additional analysis to broaden the knowledge given is encouraged. The pupils in Hans's class also ask analytical and critical questions. One pupil, for instance, examines the map in the textbook, notices what he considers to be an inadequate drawing, and asks 'Isn't Buddhism in India, too?' Hans reacts encouragingly and eagerly, and invites him to continue reading the text to obtain more information: 'Well actually it is... It is, actually...! Read!' The practice of reading in order to evaluate one's knowledge, here concerning the spread of Buddhism, is stressed as important.

The fact that analysing comments and questions are more frequent in Hans's lesson does not mean that they do not exist in Elisabeth's. A problematising and analytical comment is made by one of the pupils, for instance. In the final sequence of the lesson, Elisabeth reads out a letter that she announces as 'the world's oldest love letter', using it to show how old the phenomenon of religion is, and how the presence of a religious worldview can also be found in this particular letter. One of her pupils reacts to the description 'the world's oldest love letter', and comments by adding 'the world's oldest known love letter' - which may be understood as a relevant source-critical remark. The teacher's reply is another source-critical reflection-'mm... surviving love letter...'-followed by a change of subject. The teacher's comment has the character of a reprimand: it is meant to top the pupil's comment, although it is not certain that it does. There could of course have been older letters that do not survive, but this does not mean that there are no older letters as yet unfound. The analytical, problematising, and critical speech genre that the pupil uses can be understood as having been made less appropriate by the utterances of the teacher.

The analyses of the news-quiz lessons show that all questions 
and comments in Class A were of an informative speech genre. This genre also dominates in Class $\mathrm{C}$, but here there are also analysing and interpreting examples, and several of the pupils' contributions are of a narrative character, since they refer to their own and others' related experiences, holidays, and news.

\section{Speech genre content}

Elisabeth's class demonstrates the broadest repertoire of speech genre content in the RE introductory lessons, even if this is to a large extent due to single utterances. Most of the content in both classes concerns the relation between religion and geography. In both classes, there are also questions and comments that are about learning and thinking processes. These utterances are most common in Hans's class. In Elisabeth's classroom, there are in addition examples of discussions about source criticism, the meaning of religion as a phenomenon, and the history of religion. In Hans's class, one pupil brings up the appearance of a church, based on a reflection from the film. In both classrooms, certain concepts are stressed and made into objects of learning to a greater or lesser extent. In Class C, the concepts are monotheism, prejudice (which Hans introduces), and bindis (the decorative marks worn on the forehead that are often associated with Hindu women), which one of the pupils brings up. In Class A, the concepts introduced by the teacher are monotheism and archaeology.

The analyses of the news-quiz lessons differ from the pattern identified in the introductory lessons. Here, it is Class C that clearly has the broadest speech genre content, which both teachers' and pupils' utterances contribute to. In both classes, the questions and comments often concern political science, but also task-solving processes, as well as words and pronunciation. However, the kinds of task-solving processes differ between the classes.

In Class A, some comments related to task-solving are introducing the theme and encouraging the pupils, but the majority of the comments are achievement-directed. When the correct responses are presented Elisabeth says, 'Is there anyone who has nine correct 
answers so far? [Some people say 'Yes!'] We have some here with the chance at getting ten...' (Elisabeth). In Class A, task-solving comments that have an encouraging character are more frequent: 'And then comes the third... I reckon you'll be able to solve it. You never know, but.... Comments of a strategy-building character are highlighted in Class C. One example is how Hans, when he calls out the correct answers, shows how to use the map as a thinking tool.

H: Next question! ... was about the Åland Islands... if you look at the map, it isn't so hard, right...? [Rolls down the map]. You can see the Åland Islands... But what is that red line there? What might the red line indicate? 11 ?

11: It's a border...

$\mathrm{H}$ : A border, yes, and what... what... how can you figure out, then, which country it belongs to? Now I couldn't hear what 11 said.

11: You look for which [country] is closest.

H: Exactly... So why can't it belong to Sweden, then, if you look at the map?

11: Because the border is there...

H: There it goes, between Sweden and the Åland Islands, so it should belong to which [country]? 2 !

2: Finland!

$\mathrm{H}$ : That's right!

The example also shows how it is through the pupils' comments that Hans develops his message and makes it distinct. The incomplete comment from Pupil 11 (about looking for the country closest to the island when deciding which country it belongs to) makes Hans take a step back, and use a question to stress the meaning of the red line as a border that decides the issue, so showing what should have been added to Pupil 11's answer to make it complete.

Other speech genre content that contributes to the broader repertoire in Class $\mathrm{C}$ concerns geography, society, and culture generally, and themes that link the current subject matter to shared experiences. 


\section{Teacher positions and competent pupils}

When interpreting the findings from the RE lesson analyses by focusing on how the teacher positions and the competent pupil positions are performed in the two discursive practices, $\mathrm{A}$ and $\mathrm{C}$, teaching tools seem to be important.

In Class A, Elisabeth is the main source of information, while Hans teaches from the textbook, from which the pupils read aloud. This difference seems to give Hans a position from which he can comment on and problematise the content. Hans's position is reminiscent of an older and more competent peer who is also being presented with new information, and on this basis reflects, scrutinises, and formulates possible conclusions. The different teacher positions also facilitate different reactions and interactions in class. Elisabeth, who herself is the main source of content in her lessons, is almost offended when a pupil makes a critical comment about the content, while Hans is delighted in a similar situation and participates in the critical analysis of the textbook, which here is the source of content.

In Hans's classroom, the negotiated understanding of a competent pupil seems to be a person who is active-who discusses and analyses. In Elisabeth's classroom, the collective norms are to a larger degree related to being reserved and quiet. These different positions seem to characterise the discursive practices as a whole.

The interpretations of the analyses of the news-quiz lessons show a similar pattern. In addition, it becomes clear that Hans's peer-like position should not be mistaken for one that is less careful with regard to the planning of the lesson. The news-quiz task is given a clear purpose and has a learning-centred character. When one of the pupils wants to fill in the quiz by herself instead of discussing in class, Hans explains:

$\mathrm{H}:$...there are a lot of complicated words here, and there are many comments to make about it all... not least, you have so much to say, things and stuff, about those questions, so it isn't just what's in the questions, but we learn a lot of other stuff, too. 
Here, broadened repertoires of knowledge emerge as the central aim of the news-quiz work. In contrast, this work seems to be more of an interlude in Class A. Elisabeth and Christer introduce the work by saying that they might have forgotten the quiz if the pupils had not reminded them, and the task ends with Elisabeth saying 'Now, you can get to work'

\section{Concluding discussion}

So, what differences in communication patterns have been identified that contribute to an understanding of why the achievements and development in the RE test were found to be stronger in Class $C$ than in Class A-an achievement pattern that also occurred in the national tests in the core subjects for these two classes (Skolverket 2015)? A part of the answer may be that questions, from both teachers and pupils, are generally more frequent in Class $\mathrm{C}$, which also means that teacher intentions, pupils' knowledge, and learning processes are more visible here (for example, Hattie 2009). It is possible for the teacher to draw on the information obtained from these questions when planning and teaching. Simultaneously, the pupils may understand from the teacher's questions what he or she considers to be central knowledge.

In Class $\mathrm{C}$, the speech genres used are more analytical and varied, while they are mostly informative in A (cf. Emanuelsson 2001). One reason for this discrepancy may be that Hans avoids being the sole source of information, and instead takes a position from which he can analyse and problematise the content. It is seldom pointed out that the use of textbooks can create this advantage. Hans's problematising work also seems to encourage his pupils to do the same. When the teacher is the sole source of information, as in Class A, pupils' questioning of the content can be interpreted as a criticism of the teacher, which in turn may curb pupils' interest in further problematisations.

The repertoire concerning content of the speech genres in both $\mathrm{RE}$ classes is limited and concerns mainly the spread of religions over different regions in the world. It is worth remembering that some 
pupils actually mixed up 'religion' and 'region' in the tests (Osbeck 2014). The RE content in these lessons, of course, provides only a narrow perspective, focusing on a very limited part of the curriculum, and many of Smart's dimensions of religion (1997) are absent. The well-known domination of learning-about perspectives in RE in relation to learning-from perspectives is obvious (for example, Osbeck \& Pettersson 2009). It is important to bear in mind that these were introductory lessons, but nevertheless the findings can be read in relation to existing research patterns showing the heavy influence of geography on social studies in middle school (Kristiansson 2014; Stolare 2014). Even if Class A tackles a somewhat broader theme in this lesson, including the meaning of the phenomenon religion, the issue is brought up in such a superficial way that the theme also seems to be difficult for the teacher. This recalls the findings from the initial interviews, where the teachers' RE aims were found to be of a rather vague, general character, relating primarily to fundamental values (Osbeck 2014). In relation to research findings that stress the importance of teachers' deep understanding of the subject, their ability to problematise the themes being dealt with (for example, Hattie 2003), and to translate between different language games such as science and everyday language games (for example, Lundin 2007; Ongstad 2006), the findings from these observations seem problematic. However, the observations also show how Hans introduces a task with the purpose of mapping out his pupils' understandings, which is in line with the findings from the initial interview, where he had ideas about pupils' difficulties in RE in relation to the goals of curriculum. In the task, Hans shows an interest in examining how best to direct his teaching in future.

In the news-quiz lessons, it was clearer how the communication patterns in Class $\mathrm{C}$ offered a comparatively broader repertoire of speech genres, and how a broad use of speech genres is related to a broad body of shared experience that can be used as a link between different subjects and that constitutes a resource to draw on. The fact that the pupils in Class $\mathrm{C}$ and their teacher have worked together for a long time may in this sense be an advantage that is lacking in Class A. In relation to previous research, showing work with news in 
school to be frequent but also time-consuming, isolated, fragmentary, and weakly connected to the goals of the curriculum (for example, Kristiansson 2014; Olsson 2016), the current study stresses how different this kind of work can be, and that detailed analyses of how certain work it is conducted and communicated are needed in order to evaluate such work.

The examples have also shown how the teachers' position appears different in the two discursive practices. Hans's reflexive and analytical position, where he creates a distance between himself and the content and appears as a more competent peer, could perhaps also make his modelling ability as a learner stronger.

Similarly, pupil positions and what it means to be a competent pupil differ. In Class $C$, the position includes an active, curious, rather carefree, and talkative way of being, where one shares experiences without feeling inhibited, while almost the opposite is true for Class A. Whether these patterns can be related to the fact that there are almost twice as many pupils in Class A as in Class C, that the pupils and teachers in Class $\mathrm{C}$ have worked together for a long time, and that the pupils in Class $\mathrm{C}$ have a habit of working collectively, are questions of further interest. However, the Class A's discursive practice appears rather controlled and restricted, whereas Class C's comes across as permissive and creative-a practice where knowledge is explored and problematised.

Despite the similarities in the classes' lessons, the study shows the differences in the communicative patterns, which can contribute to an understanding of the comparatively advantageous development in Class C, indicated by the RE tests (Osbeck 2017). Communicative patterns in a classroom are not, however, something that the teacher alone determines. As we have seen, it is something that is negotiated collectively.

\section{The didactical consequences}

Unfortunately, there is not much previous research in the field of RE didactic classroom studies with which to compare. While it adds to the novelty value of the study, it is hard to know how best to direct 
such a study in order to contribute with findings that challenge or confirm the knowledge field. However, since this study is partly theory-driven it is possible to chart the logic of the theoretical perspectives on a general level, and to contribute by demonstrating how these perspectives can appear in the complex reality of RE and social studies classrooms. In this essay, a couple of useful studies from other fields of subject-matter didactics are noted, indicating that another state of the art-one constructed across subject-matter didactical fields-might have been beneficial. However, the discussion here shows how RE research, with its connections to the wider field of social studies, can contribute to the current study with valuable perspectives for interpreting and understanding the findings.

'Didactical consequences' can be understood as the implicit focus of this empirical study. One can say that it is the potential didactical consequences of certain communication patterns, discursive practices, and speech genres that are explored and discussed here. The concept grasps the focus of this didactical RE classroom study where the complex interactional processes between pupils and teachers concerning specific content are highlighted-with an emphasis on the teacher's positions and opportunities. Didactical consequences thus describe the performances that take place in the classroom thanks to that communication.

But what further didactical consequences might this study have for RE practice beyond the empirical cases examined? The findings raise awareness of the importance of communication patterns, how speech genres in classroom may vary and how teachers through their way of initiating and responding to questions influence these patterns. The findings may contribute with an awareness of the intertwining of form and content in teaching and learning, and an understanding of teaching and learning as linked to the discursive classroom practice as a whole, including its specific teacher and pupil positions. More specifically, didactical consequences of this study may be an understanding of how both pupil and teacher questions are important in order to make knowledge and learning visible, of how analytical and problematising speech genres become central in learning processes and seem to create curiosity. An insight about how a pupil-oriented 
teacher position where the teacher becomes a role model while acting as one of the learners, albeit a more experienced and skilled learner, is a central implication of the current study-perhaps hinting at the potential benefit in avoiding being the sole source of information. The didactical consequences of this study might be new collegial conversations about the actions to take in order to encourage pupils to be more talkative, curious, and linguistically advanced, practising both the languages of religion and the languages of life.

\section{References}

Afdal, G. (2015), 'Modes of learning in religious education', British Journal of Religious Education, 37/3, 256-72.

Bach, F., B. Frändberg, M. Hagman, E. West \& A. Zetterqvist (2015), 'De nationella proven i NO åk 6: Skillnader i resultat mellan olika grupper', Educare 2, 48-70.

Bakhtin, M. (1986), Speech genres and other late essays (Austin: University of Texas Press).

Buchardt, M. (2008), Identitetspolitik i klasserummet: 'Religion' og 'kultur' som viden og social klassifikation: Studier i et praktiseret skolefag (Copenhagen: Københavns universitet).

Emanuelsson, J. (2001), En fråga om frågor: Hur lärares frågor $i$ klassrummet gör det möjligt att få reda på elevernas sätt att förstå det som undervisningen behandlar i matematik och naturvetenskap (Gothenburg: Göteborgs universitet).

Englund, T. (2000) 'Kommunikation och meningsskapande i fokus: Ett sociopolitiskt perspektiv på det vi kallar undervisning och lärande’, in C. A. Säfström and P. O. Svedner (eds.), Didaktik (Lund, Studentlitteratur).

Foucault, M. (1989). The archaeology of knowledge. (London: Routledge).

Grimmitt, M. (1987), Religious education and human development (Great Wakering: McCrimmon).

Hattie, J. (2003), 'Teachers Make a Difference: What is the research evidence?' paper presented to the ACER, Melbourne Australia, 19-21 October, http:// research.acer.edu.au/research_conference_2003/4.

- - (2009), Visible learning: A synthesis of over 800 meta-analyses relating to achievement (London: Routledge).

Lippe, M. von der (2011), Youth, Religion and Diversity: A qualitative study of young people's talk about religion in a secular and plural society: A Norwegian case (Stavanger: University of Stavanger).

Karlsson, A. (2015), Vilket religionskunskapsämne? Ämneskonstruktioner i 
religionskunskap på gymnasiet med samtalsförhandlingar i centrum (Karlstad: Karlstads Universitet).

Kittelmann Flensner, K. (2015), Religious education in contemporary pluralistic Sweden (diss., Gothenburg: Göteborgs universitet).

Kristiansson, M. (2014), 'Samhällskunskapsämnet och dess ämnesmarkörer på svenskt mellanstadium: Ett osynligt eget ämne som bistår andra ämnen', Nordidactica-Journal of Humanities \& Social Science Education, 1, 212-33. Kyriakides, L. \& B. Creemers (2008), 'Using a Multidimensional Approach to Measure the Impact of Classroom-Level Factors upon Student Achievement: A Study Testing the Validity of the Dynamic Model', School Effectiveness \& School Improvement, 19/2, 183-205.

Krathwohl, D. R. (2002) 'A Revision of Bloom's Taxonomy: An Overview', Theory into Practice, 41/4, 212-18.

Liljestrand, J. (2002), Klassrummet som diskussionsarena (Örebro: Örebro universitet).

Lundin, M. (2007), 'Questions as a tool for bridging science and everyday language games', Cultural Studies of Science Education, 2, 265-79.

Nicolaisen, T. (20013), Hindubarn i grunnskolens religions- og livssynsundervisning: Egengjøring, andregjøring og normalitet (Oslo: Universitetet i Oslo). Nordenbo, S. E., Søgaard Larsen, M., Tiftikçi, N., Wendt, R. E. \& Østergaard, S. (2008), Teacher Competences and Pupil Achievement in Pre-school and School: A Systematic Review Carried Out for the Ministry of Education and Research, Oslo (Copenhagen: Danish Clearinghouse for Educational Research, School of Education, University of Aarhus).

Olsson, R. (2016), Samhällskunskap som ämnesförståelse och undervisningsämne: Prioriteringar och nyhetsanvändning hos fyra gymnasielärare (Karlstad: Karlstads Universitet).

Ongstad, S. (2006), 'Fag i endring: Om didaktisering av kunskap', in id. (ed.), Fag og fagdidaktikk i lorerutdanning: Kunnskap i grenseland (Oslo: Universitetsforlaget).

Osbeck, C. (2009), Att förstå livet: Religionsdidaktik och lärande i diskursiva praktiker (Uppsala: Svenska kyrkan).

- - \& Pettersson, P. (2009), 'Non-confessional and confessional education: Religious education in public schools and in the Church of Sweden', in U. Riegel \& H.-G. Ziebertz (eds.), How Teachers in Europe Teach Religion: An International Empirical Study in 16 Countries (Münster: LIT-Verlag).

- - \& Lied, S. (2012), 'Hegemonic speech genres of classrooms and their importance for RE learning', British Journal of Religious Education, 34/2, 155-68.

- - (2013) 'Social Studies: One Context in which Central RE Knowledge in Sweden is Constructed', in G. Skeie, J. Everington, I. ter Avest \& S. Miedema (eds.), Exploring Context in Religious Education Research: Empirical, Methodological and Theoretical Perspectives (Münster: Waxmann). 
- - (2014), 'Conditions for Teaching and Learning in Religious Education (RE): Perspectives of Teachers and Students at the Beginning of the 6th Grade in Sweden', Nordidactica: Journal of Humanities \& Social Science Education, 2, 76-96.

- - (2017), 'Knowledge Development of Tweens in RE: The Importance of School Class and Communication', British Journal of Religious Education, 1-14. Postman, N. (1998), När skolans klocka klämtar: Om behovet av meningsskapande berättelser (Gothenburg: Daidalos).

Skogar, B. (2000), 'Religionsdidaktikens kärnproblem', in M. Linnarud (ed.), På spaning efter ämnets kärna: didaktiska tankar kring några skolämnen (Karlstad: Universitetstryckeriet).

Skolverket (Swedish National Agency for Education) (2011), Curriculum for the Compulsory School, Preschool Class and the leisure-time Centre 2011. (Stockholm: Fritzes).

-_ (2015), SiRiS: Kvalitet och resultat i skolan [database], [WWW dokument]. URL http:// siris.skolverket.se/siris/f?p=SIRIS:33:0 (2015-05-22). See also https://www.skolverket.se/skolutveckling/statistik

Smart, N. (1997), Dimensions of the sacred: An anatomy of the world's beliefs (London: Fontana Press).

Stolare, M. (2014), 'På tal om historieundervisning: Perspektiv på undervisning i historia på mellanstadiet', Acta Didactica Norge-Tidsskrift for Fagdidaktisk Forsknings-og Utviklingsarbeid i Norge, 8/1, 1.

Säljö, R. (2005), Lärande och kulturella redskap: Om lärprocesser och det kollektiva minnet (Stockholm: Norstedts).

Tappan, M. B. (1992), 'Texts and contexts: Language, culture, and the development of moral functioning', in L. T. Winegar \& J. Valsiner (ed.), Children's development within social context, $\mathrm{i}$ : Metatheory and theory (Hillsdale: Lawrence Erlbaum).

Wertsch, J. V. (1991), Voices of the mind: A Sociocultural approach to mediated action (Cambridge, MA: Harvard University Press ). 